\section{Local-Level Site-Selection Model for Integrated Carsharing Services}

GI_Forum 2016, Vol.1

Page: 243-249

Short Paper

Corresponding Author:

johannes.schwer@geo.uni-augsburg.de

DOI: 10.1553/giscience2016_01_s243

\author{
Johannes Schwer and Sabine Timpf \\ University of Augsburg, Germany
}

\begin{abstract}
Round-trip carsharing services, particularly when integrated with other transport options, have been proven to represent a viable means to mitigate the negative impacts of individual motorized traffic in dense urban areas. An increasing number of cities, therefore, aim to integrate carsharing with local public transport as an additional mobility option which promotes sustainable transport patterns. However, selecting appropriate sites for carsharing pods remains a difficult task for decision-makers since both integration with public transport as well as maximization of coverage of potential customers/market share have to be achieved. In this context, we present a GIS-based site-selection model that includes criteria from both the demand and the supply sides at the local level. On the demand side, the spatial distribution of demand is addressed by incorporating the spatial accessibility of local amenities and transport options, as well as socio-demographic and behavioural criteria. On the supply side, the key aspect is the integration of carsharing pods with public transport. Potential sites were assessed at the level of individual buildings, based on their proximity to public transport infrastructure, their centrality, and the residential locations of regular public transport users.
\end{abstract}

\title{
Keywords:
}

carsharing, site selection, suitability modelling

\section{Motivation and Background}

It is widely acknowledged that economic and societal prosperity within urban spaces is closely linked to efficient as well as sustainable transport systems. Nevertheless, increasing motorization, predominantly through conventional vehicles, reduces the "liveability" of urban areas. More specifically, pressures on parking spaces, congestion, heavy land use, noise pollution and exhaust emissions continue to build up in our cities. Recent decades have seen a wide range of concepts for sustainable transport systems being developed. However, various key challenges remain. These include, but are not limited to, reducing private car ownership and the number of trips made by car while maintaining a high level of individual mobility (Umweltbundesamt, 2015). 
Carsharing schemes, particularly when integrated with public transport, have been proven to represent viable means to mitigate the negative impacts of individual motorized transport. At the same time, and especially in dense urban areas, the shared use of cars can help to reduce private vehicle ownership and the number of trips made by car, but without substantially restricting individual mobility. In the case of round-trip carsharing, registered users are required to book a car in advance; pricing is based on the distance driven and the duration of the trip, and the vehicle has to be picked up from and returned to the same location (pod). In the presence of high-quality public transport as well as walking and cycling infrastructure, however, these constraints are reported to promote the use of multiple modes of transport or mobility, because users are encouraged to reflect on their individual choices. Having access to shared vehicles as one of multiple mobility options, customers are able to adopt less car-dependent, and more flexible and sustainable mobility patterns.

When planning a carsharing service, it is therefore vital to make carsharing pods conveniently accessible to the maximum number of potential users to ensure the scheme's profitability. The attractiveness of carsharing as an additional mobility option depends, further, on its close spatial integration with public transport, which serves as the backbone of sustainable transport (Huwer, 2003; Loose, 2012). Decision-makers facing this facility-location problem, however, can hardly rely on precise information regarding spatial distribution of demand prior to launching the service. Furthermore, to our knowledge, there is no well-established method to evaluate spatial integration of carsharing pods with public transport.

In this context, i.e. in the absence of a priori data of spatial-demand distribution, the main goal of this study was the identification and assessment of candidate sites within an urban area. An accessibility-based model was developed, therefore, to estimate spatial suitability of potential sites at the local level, from demand as well as supply perspectives. These considerations were used as weights in a location-allocation analysis of where carsharing pods might best be located, the objective being to optimize the spatial distribution of the pods to reach the largest market share possible.

\section{Site-Selection Modelling for Carsharing}

Insights from socio-demographic, attitude- and preference-based approaches, as well as geographic ones, to market segmentation for carsharing can be found in various published sources (Braun et al., 2013; Celsor \& Millard-Ball, 2007; Krietemeyer, 2012). A comprehensive activity-based simulation has also been used to estimate carsharing demand (Ciari et al., 2013). However, its application requires socio-demographic, behaviour- and attitude-based data at the individual level. Normally, such precise data is not available for entire cities, or it is not accessible to operators of local carsharing services. Additionally, it has been shown that socio-demographic background as well as reasons for using shared vehicles vary substantially amongst customers (Celsor \& Millard-Ball, 2007). This aspect further complicates the estimation of individual demand. Geographic market segmentation approaches, however, suggest significant interdependencies between locations of carsharing sites and the built environment, which can be addressed using widely available spatial data and GIS-based methods. However, experience with incorporating known locational factors 
into the site-selection process has, by and large, not been shared with the scientific community. Hence, the proposed model (see Figure 1) is an applied synthesis of congruently-reported findings regarding market segmentation and location factors for carsharing pods. The overall model has two parts: (1) a three-tier spatial suitability model for assessing spatial units such as buildings or plots of land, from both demand and supply perspectives, in order to identify and rate potential sites and points of high demand for carsharing; (2) a weighted location-allocation analysis (Tomintz et al., 2015).

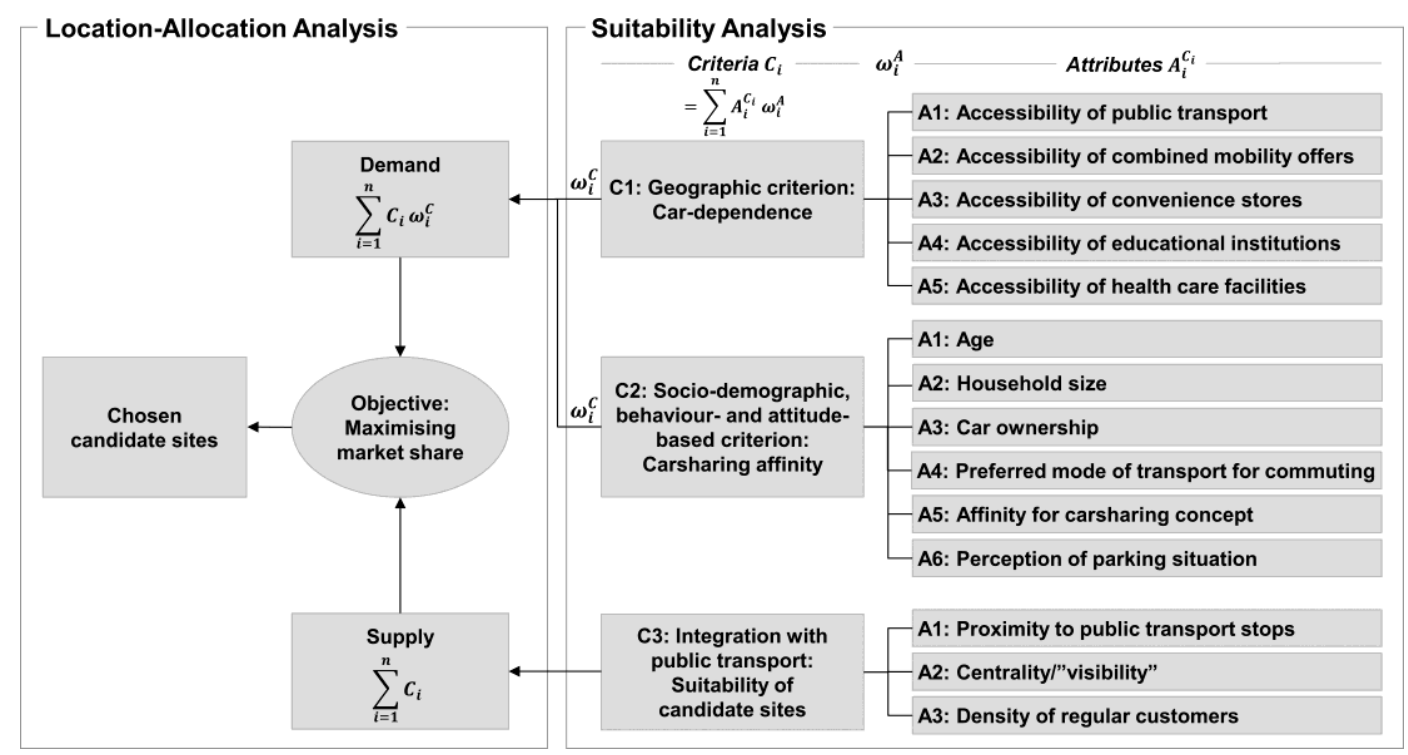

Figure 1: Proposed site-selection model for round-trip carsharing based on suitability and locationallocation analysis

With respect to developing integrated transport services, the main contribution of the proposed model is the integration of suitability factors from both the demand and the supply perspectives in a weighted, network-based, location-allocation analysis. Calculated as a weight for each potential demand source (e.g. residential locations, customers), demand-side suitability represents a relative measure of structural feasibility (C1) and individual "willingness" (C2) to use a carsharing service. However, not all available plots, associated parking spaces and potential customers are equally suited for establishing a carsharing pod. Thus, candidate sites are derived separately from, and rated by, supply-side suitability (C3). Initial configuration of the weights $\omega_{i}$ may be derived from the literature or expert knowledge.

On the demand side, it is assumed that an individual's ability and willingness to adopt new modes of transport, which supplement or even substitute a private vehicle, are determined by the number and quality of transport options as well as the accessibility of local amenities (Ackermann et al., 2014; Gather et al., 2008). However, public transport, walking and cycling infrastructures, and availability of local amenities are unevenly distributed: bus and tram 
services are restricted to linear routes and amenities are often concentrated in town-centre districts and central locations of residential neighbourhoods like their main street. Residential locations having both good access to a wide variety of amenities as well as mobility options allow their residents to realize sustainable travel patterns. As is shown in different studies, carsharing users often live in dense urban areas where these prerequisites are met (Celsor \& Millard-Ball, 2007). These authors found carsharing supply to be correlated with a perception of high pressure on parking spaces (and low rate of car ownership) in densely populated and busy urban neighbourhoods. In central areas, characterized by high population density as well as numerous local amenities for shopping, health care, education and transport options, residents are less dependent on a private vehicle than residents of more peripheral places. Moving the focus from the individual to his/her surrounding geographic space, the suitability model incorporates car-dependence at the very local level as a measure for determining the degree to which living in an individual residential location is objectively dependent on having a personal vehicle (Siedentop et al., 2013). This measure aims to assess the general practicability of carsharing in a combined-mobility context, without the influence of subjective factors such as personal preferences, and attitudes such as car reliance. Sociodemographic, behaviour- and attitude-based attributes typically associated with carsharing users are also included in the model but restricted to widely-reported indicators (Braun et al., 2013; Celsor \& Millard-Ball, 2007; Krietemeyer, 2012). While the typical profile of carsharers can be derived from municipal data (age group ca. 20-40, one- or two-person household, low car ownership, commuting by public transport or active modes), affinity for the carsharing concept and perception of the parking situation are hard to determine. Geographic as well as both socio-demographic and attitude-based criteria are interdependent. However, geographic criteria have been found to be reasonable proxies for the latter two (Celsor \& Millard-Ball, 2007).

On the supply side, three main features have been identified in the literature for integration of carsharing pods with public transport. (1) The most obvious is proximity to public transport stops with frequent services, since carsharing users are reported to show high affinity towards active transport modes and public transport (Krietemeyer, 2012). From a spatial perspective, carsharing demand is assumed to increase towards public transport stops. Hence, pods should be located close to areas with high estimated demand or known customers (Loose, 2009). (2) While business users create demand in comparatively central areas, private customers will require carsharing supply close to their residential location. Consequently, carsharing demand is also characterized by land use. In focusing on users of public transport, this aspect was not covered, but it may be included in future work. (3) When looking for sites where carsharing pods could actually be installed, their visibility from public street space is important for marketing, security and accessibility reasons (Loose, 2009; Sonnberger \& Gallego Carrera, 2013). However, in the preliminary process of identifying candidate sites, the criterion of visibility alone is not sufficient because it neglects the spatial distribution of visit probability. Hence, the conclusion was drawn that centrality measures provide more meaningful indicators for frequently visited and therefore "visible" sites. Figure 2 shows an example of supply-side suitability for Augsburg (Germany), used for identifying and rating potential sites. Drawing on a pedestrian network data set, service areas for each public transport stop were calculated and assigned decreasing weights up to a maximum walking distance of $600 \mathrm{~m}$. Additionally, the stops were differentiated based on 
elementary measure of services (tram: yes/no; number of routes). Supposedly highly central locations were derived using the same pedestrian network by computing a gravity-based centrality measure for each building (Sevtsuk \& Mekonnen, 2012). Relying on address data of regular users of public transport, it was possible to quantify the density of users per building and aggregate the supply-side attributes into a relative suitability measure.

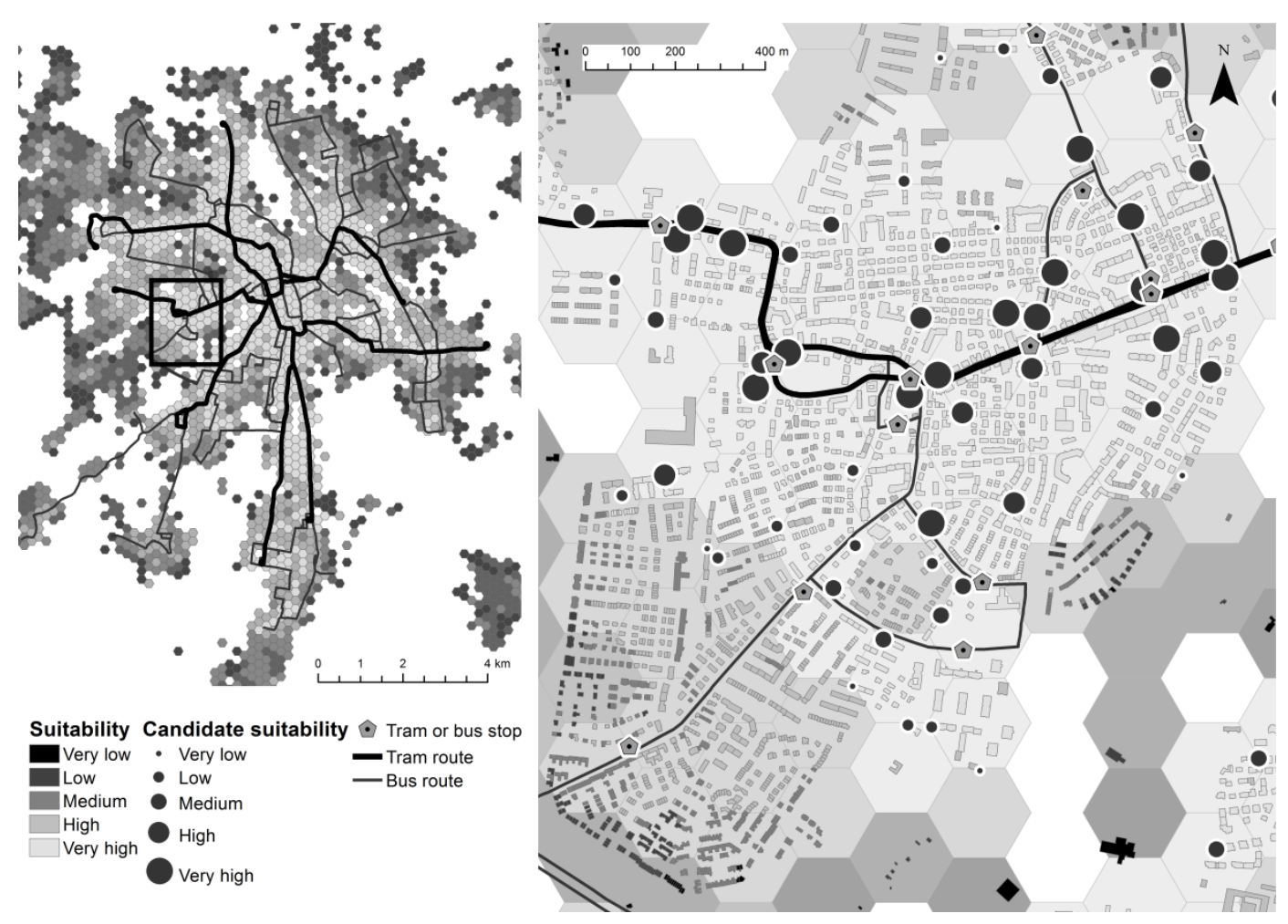

Figure 2: GIS-based assessment of supply-side spatial suitability for carsharing pods (Figure 1: C3) at building level. Suitability was also aggregated within cells (width $200 \mathrm{~m}$ ) to provide a comprehensible overlay to support decision-making.

Finally, the best-suited building within each cell was selected as a candidate site (see Figure 2) for the network-based location-allocation analysis. Since only a limited number of pods can be installed, location-allocation analysis was used to identify a predetermined number of highly suited candidate sites to serve a maximum proportion of the weighted demand with maximum efficiency. This approach allows recommendations for site selection to be made for various scenarios of service expansion. 


\section{Results and Conclusion}

A GIS-based model for site-selection for carsharing pods was developed. Incorporating factors of demand as well as of supply, this model allows the assessment of the suitability of potential sites for carsharing pods at the level of individual buildings. Furthermore, by quantifying car-dependence as a geographic measure of accessibility and by including sociodemographic and behavioural criteria, it is possible to approximate the relative spatial distribution of demand. Generally speaking, this measure may be interpreted as identifying poorly accessible areas. Combining both weighted supply and demand sites, locationallocation analysis can be used to optimize the spatial distribution of carsharing pods for specific planning scenarios (e.g. with the objective of maximizing market share). The implementation of an integrated carsharing scheme in Augsburg (swa Carsharing), based on our approach, is ongoing. Our future involvement will include a posteriori calibration and evaluation of the model necessary to represent actual demand and investigate causal interdependences of parameters. Aimed at facilitating an initial site-selection process during the recent development of swa Carsharing in Augsburg, however, the results of the model could serve as valuable spatial guidance for decision-makers in the systematic search for available parking spots where carsharing pods could actually be installed. Since most input attributes may be quantified at a very local level using data available through municipal authorities or free sources like OpenStreetMap, transferring this site-selection model to different areas could provide cost-effective, straightforward and informed support for GISbased decisions in selecting carsharing sites.

\section{Acknowledgments}

This study was supported by public utility company Stadtwerke Augsburg, the operators of swa Carsharing.

\section{References}

Ackermann, T., Loose, W., \& Reining, C. (2014). Die Verknüpfung von Carsharing und ÖPNV. In Bundesverband CarSharing e.V. (bcs) (Ed.), Verkehrspraxis. Eine Idee setzt sich durch! 25 Jahre CarSharing (pp. 111-121). Köln: ksv kölner stadt- und verkehrsverlag.

Braun, A., Hochschild, V., \& Koch, A. (2013). Intraregionale Unterschiede in der CarsharingNachfrage: Eine GIS-basierte empirische Analyse. IAW-Diskussionspapiere. (99), 1-23. Retrieved from http://hdl.handle.net/10419/92988

Celsor, C., \& Millard-Ball, A. (2007). Where Does Carsharing Work? Using Geographic Information Systems to Assess Market Potential. Annual Meeting of the Transportation Research Board. Retrieved from http://people.ucsc.edu/ adammb/publications/Celsor_MillardBall_2007_Where_Does_CarSharing_Work_TRBversion.pdf

Ciari, F., Schuessler, N., \& Axhausen, K. W. (2013). Estimation of Carsharing Demand Using an Activity-Based Microsimulation Approach: Model Discussion and Some Results. International Journal of Sustainable Transportation, 7(1), 70-84. 
Gather, M., Kagermeier, A., \& Lanzendorf, M. (2008). Geographische Mobilitäts- und Verkehrsforschung: Mit 24 Tabellen. Studienbücher der Geographie. Berlin: Borntraeger.

Huwer, U. (2003). Kombinierte Mobilität gestalten: Die Schnittstelle ÖPNV-Carsharing (Dissertation). Universität Kaiserslautern, Kaiserslautern.

Krietemeyer, H. (2012). Effekte einer langjährigen Marketing-Kooperation zwischen dem Münchner Verkehrs- und Tarifverbund (MVV) und der Car-Sharing-Organisation STATTAUTO München. In W. Loose \& M. Glotz-Richter (Eds.), Verkehrspraxis. Car-Sharing und ÖPNV. Entlastungspotenziale durch vernetzte Angebote (pp. 99-116). Köln: ksv kölner stadt- und verkehrsverlag.

Loose, W. (2009). Carsharing als stadtverträgliche Mobilität. In W. Christ (Ed.), Access for All (pp. 134-143). Basel: Birkhäuser.

Loose, W. (2012). Car-Sharing als Ansatzpunkt zur vernetzten Mobilitätsgestaltung. In W. Loose \& M. Glotz-Richter (Eds.), Verkehrspraxis. Car-Sharing und ÖPNV. Entlastungspotenziale durch vernetzte Angebote (51-61). Köln: ksv kölner stadt- und verkehrsverlag.

Sevtsuk, A., \& Mekonnen, M. (2012). Urban network analysis. A new toolbox for ArcGIS. Revue internationale de géomatique, 22(2), 287-305.Siedentop, S., Roos, S., \& Fina, S. (2013). Ist die „Autoabhängigkeit“ von Bewohnern städtischer und ländlicher Siedlungsgebiete messbar? Raumforschung und Raumordnung, 71(4), 329-341.

Sonnberger, M., \& Gallego Carrera, D. (2013). Konzepte des kollektiven Individualverkehrs - Ein Literaturbericht. In M. Sonnberger, D. Gallego Carrera, \& M. Ruddat (Eds.), Teilen statt besitzen. Analysen und Erkenntnisse zu neuen Mobilitätsformen. Literaturangaben (1st ed., pp. 10-42). Bremen: EHV.

Tomintz, M., Clarke, G. P., \& Alfadhli, N. (2015). Location-Allocation Models. In C. Brunsdon \& A. Singleton (Eds.), Geocomputation. A practical primer (pp. 185-197). Los Angeles: SAGE.

Umweltbundesamt (UBA). (2015). Daten zur Umwelt 2015: Umwelttrend in Deutschland. Bonn. Retrieved

fromhttp://www.umweltbundesamt.de/sites/default/files/medien/378/publikationen/daten_zur _umwelt_2015_1.pdf 